\title{
A FELÜLETVASALÁS FELKEMÉNYEDÉSRE ÉS FESZÜLTSÉGÁLLAPOT-VÁLTOZÁSRA GYAKOROLT HATÁSÁNAK ELEMZÉSE
}

\author{
Ferencsik Viktória \\ egyetemi tanársegéd, Miskolci Egyetem, Gyártástudományi Intézet \\ 3515 Miskolc, Miskolc-Egyetemváros, e-mail: ferencsik.viktoria@uni-miskolc.hu \\ Varga Gyula \\ egyetemi docens, Miskolci Egyetem, Gyártástudományi Intézet \\ 3515 Miskolc, Miskolc-Egyetemváros, e-mail: gyula.varga@uni-miskolc.hu
}

\begin{abstract}
Absztrakt
Jelen tanulmányban az élettartam-növelö felületszilárditó eljárások közé tartozó vasalás technológiájának vizsgálatával, az azzal kapcsolatos eredmények bemutatásával foglalkozunk. Analizáljuk, hogy a megmunkálás során beállitott paraméterek (vasalási erö, elötolás, sebesség, járatszám) milyen hatással vannak a felületi mikro-keménységre, valamint a feszültségállapotra, illetve elemezzük a köztük lévö korrelációs kapcsolatokat. A kísérletek megtervezése és végrehajtása a teljes faktoriális kísérlettervezés módszerével történik.
\end{abstract}

Kulcsszavak: gyémántvasalás, mikro-keménység, maradó feszültség, teljes faktoriális kísérlettervezés

\begin{abstract}
In this study the technology of lifetime increasing surface strengthening burnishing process is inestigated presentig the results related to it. We analyze the effect of setting parameters (burnishing force, feed rate, speed, number of passes) to the surface micro-hardness and stress condition and examine the correlation relationships between them. To planning and executing the experiments use full factorial experimental design method is applied.
\end{abstract}

Keywords: diamond burnishing, micro-hardness, residual stress, full factorial experimental design

\section{Bevezetés}

A vasalás, mely eredetileg vasúti tengelyek megmunkálására kifejlesztett [1] befejező eljárás, ma már jelentős szerepet tölt be a hideg képlékeny alakító technológiák között. Az eljárásnak számos előnye van: csökkenti a felületi érdességet, növeli a mikro-keménységet, továbbá javítja a megmunkált darab feszültségállapotának jellemzőit, ráadásul nem igényli nagy mennyiségü hütő-kenő folyadék alkalmazását, tehát gazdaságos és kis környezetterhelésü [2-5].

A felületvasalás egyaránt alkalmas külső és belső hengeres felületek megmunkálására, követheti napjaink modern forgácsoló megmunkálásait is, ezért a minél hatékonyabb alkalmazás érdekében a módszer minél részletesebb elméleti és gyakorlati vizsgálata szükséges.

Kutatómunkánk során külső hengeres felület gyémántszerszámos felületvasalásával, illetve az általa okozott felületi mikro-keménység és maradó feszültség változásával foglalkozunk. A kísérletek megtervezéséhez és végrehajtásához a teljes faktoriális kísérlettervet alkalmazzuk, mellyel empirikus képletek hatékonyan meghatározhatóak, továbbá, az eredményeket speciális viszonyszámok képzésével értékeljük ki. 


\section{Az eljárás alkalmazása külső hengeres felületen}

Tengelyszerủ darabok vasalása során a forgó mozgást végző munkadarab (1) felületén egy adott paraméterekkel rendelkező szerszám (2) meghatározott nyomóerővel, egyenes vonalú mozgást végezve végighalad, ezzel átfedést hozva létre a szerszám müködő és a munkadarab alakítandó felülete között, így a forgácsolás utáni felületi zónában lévő húzó maradó feszültség [6,7], kedvező nyomó maradó feszültségé alakul, ahogy az 1. ábra szemlélteti.
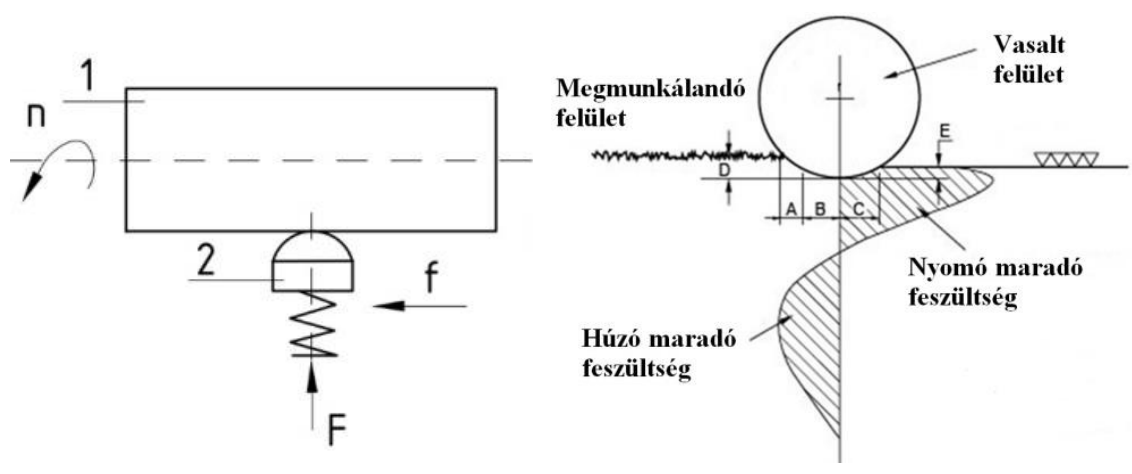

1. ábra $A$ vasalási müvelet kinematikája és hatása. [4]

A: gördülési zóna, B: rugalmas deformáció zóna, C: simítási zóna, D: nyomás alatt tartott réteg, E: rugalmas deformáció

Hozzájárulva ugyancsak az élettartam növekedéshez egy másik szilárdságnövelö mechanizmus is fellép, az alakítási keményedés, a továbbiakban a felületi mikro-keménység és a maradó feszültség vizsgálatát részletezzük.

\section{Kísérleti körülmények}

\subsection{A vizsgálat tárgya}

A kísérletsorozatokhoz gyengén ötvözött alumíniumot választottunk (EN AW-2011), mivel az autó-, repülőgép- és üripari vállalatok egyre inkább megkövetelik a nem-vasalapú anyagok alkalmazását [810], köszönhetően azok alacsony sürüségének és jó mechanikai tulajdonságainak.

A vasalási müveleteket $\mathrm{f}_{1}=0,2$ majd $\mathrm{f}_{2}=0,15 \mathrm{~mm} /$ ford előtolással beállított simító esztergálás elözte meg, ezt követte az $\mathrm{R}=3,5 \mathrm{~mm}$ méretű $\mathrm{PCD}$ (polycrystalline diamond) szerszámmal végzett vasalás.

\subsection{A teljes faktoriális kísérlettervezés}

A 2. ábrán látható az alkalmazott kísérlettervezési módszer alapmodellje.

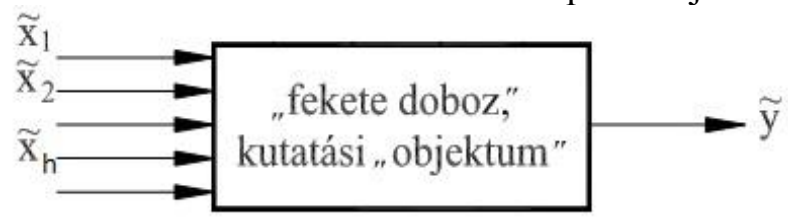

2. ábra A kísérlettervezés alapmodellje. [11] 
A cél a függő változó $(\tilde{y})$ és a független változók $\left(\widetilde{x_{h}}\right),(\mathrm{h}=1 \ldots \mathrm{f})$ közötti függvénykapcsolat meghatározása. Mindegyik független változó, vagyis faktor több értéket vehet fel, melyeket szinteknek $\left(\mathrm{p}_{\mathrm{j}}\right) ;(\mathrm{j}=1 \ldots \mathrm{m})$ nevezünk.

A kísérletek során faktorként a vasalási járatszám (i), sebesség (v), előtolás (f), vasalóerő (F) szerepel.

\subsection{A vasalási paraméterek}

A továbbiakban a számos megvalósított kísérleti vizsgálataink közül 2 esetet mutatunk be jelen cikkben.

A kísérlettervezési módszernek megfelelően a kiválasztott faktorok értékeit 2 szintre állítottuk be, ezt foglalja össze az 1. táblázat.

1. táblázat. Vasalási paraméterek

\begin{tabular}{|c|c|c|c|c|c|c|c|c|c|}
\hline \multirow{2}{*}{ Ssz. } & \multicolumn{3}{|c|}{ Vasalási paraméterek I. } & \multicolumn{3}{c|}{ Vasalási paraméterek II. } & \multicolumn{3}{c|}{$\begin{array}{c}\text { Transzformált } \\
\text { paraméterek }\end{array}$} \\
\cline { 2 - 10 } & $\mathrm{i}[\varnothing]$ & $\mathrm{f}[\mathrm{mm} / \mathrm{ford}]$ & $\mathrm{F}[\mathrm{N}]$ & $\mathrm{F}[\mathrm{N}]$ & $\mathrm{f}[\mathrm{mm} / \mathrm{ford}]$ & $\mathrm{v}[\mathrm{m} / \mathrm{min}]$ & $\mathrm{x}_{1}$ & $\mathrm{x}_{2}$ & $\mathrm{x}_{3}$ \\
\hline 1 & 1 & 0,001 & 10 & 10 & 0,001 & 15 & -1 & -1 & -1 \\
\hline 2 & 3 & 0,001 & 10 & 20 & 0,001 & 15 & +1 & -1 & -1 \\
\hline 3 & 1 & 0,005 & 10 & 10 & 0,005 & 15 & -1 & +1 & -1 \\
\hline 4 & 3 & 0,005 & 10 & 20 & 0,005 & 15 & +1 & +1 & -1 \\
\hline 5 & 1 & 0,001 & 20 & 10 & 0,001 & 30 & -1 & -1 & +1 \\
\hline 6 & 3 & 0,001 & 20 & 20 & 0,001 & 30 & +1 & -1 & +1 \\
\hline 7 & 1 & 0,005 & 20 & 10 & 0,005 & 30 & -1 & +1 & +1 \\
\hline 8 & 3 & 0,005 & 20 & 20 & 0,005 & 30 & +1 & +1 & +1 \\
\hline
\end{tabular}

A számszerü értékek meghatározása során korábbi elméleti és gyakorlati kutatómunkák eredményeit vettük figyelembe.

\subsection{A felület mikro-keménységének mérése}

A felület mikro-keménységének mérését 3 ponton $120^{\circ}$-onként valósítottuk meg Wilson Instruments Tukon 2100B Vickers keménységet mérö berendezésen.

Vizsgálataink során a keménység változásának szemléletesebbé tételéhez dimenzió nélküli viszonyszámokat hoztunk létre, melyet az alábbi képletek segítségével számítottunk ki:

$$
\begin{aligned}
& \rho_{H V}=\frac{H V_{\text {vasalt }}}{H V_{\text {esztergált }}} \\
& \Delta \rho_{H V} \%=\left(\rho_{H V}-1\right) \cdot 100 \%
\end{aligned}
$$

, ahol:

$\rho_{\mathrm{HV}} \quad$ A vizsgálati jellemző (keménység) dimenziótlan javulási viszonyszáma

$\mathrm{HV}_{\text {vasalt }} \quad$ Vasalás utáni keménység,

$\mathrm{HV}_{\text {esztergált }}$ Esztergálás utáni keménység,

$\Delta \rho_{\mathrm{HV}} \% \quad$ A javulási viszonyszám változásának százalékos értéke

Minél nagyobb a viszonyszám értéke, annál nagyobb mértékü javulás, vagyis keménységnövekedés tapasztalható a vasalás következtében. 


\subsection{A maradó feszültség mérése}

A képlékenyalakítást kísérő rugalmas alakváltozás az erőhatás irányának megfelelően torzítja a kristályrácsot, ez a torzulás pedig a ható erő megszünte után is megmaradhat, erre mondjuk, hogy az anyag maradó feszültséggel terhelt [12].

A választott röntgendiffrakciós vizsgálat elve, hogy a maradó feszültség az anyagban a rácspontokban elhelyezkedő atomtörzsek egyensúlyi helyzetből való kimozdulását eredményezi, vagyis megváltoztatja az elemi cella méretét, köbös rendszerben a rácsparaméterét. Továbbá, az anyagban megváltozik a rácssíkok távolsága is és ennek a mérésével visszaszámolható a feszültség.

Tehát maradó feszültség meghatározásakor - a mérésnél beállított röntgensugárzás hullámhosszából - a rácssík-távolság megváltozása okozta ún. Bragg-szög eltolódását mérjük a Bragg-egyenlet felhasználásával [13-14]. A mérést tangenciális és axiális irányban is megvalósítottuk.

A feszültség vizsgálata során az alábbi viszonyszámokat alkottuk meg:

, ahol:

$$
\begin{aligned}
& \rho_{\sigma}=\frac{\left|\sigma_{\text {vasalt }}\right|}{\left|\sigma_{\text {esztergált }}\right|} \\
& \Delta \rho_{\sigma} \%=\left(\rho_{\sigma}-1\right) \cdot 100 \%
\end{aligned}
$$

$\rho_{\sigma} \quad$ A vizsgálati jellemző (maradó feszültség) dimenziótlan javulási viszonyszáma

$\sigma_{\text {vasalt }} \quad$ Vasalás utáni maradó feszültség,

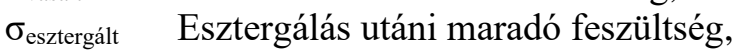

$\Delta \rho_{\sigma} \% \quad$ A javulási viszonyszám változásának százalékos értéke

Akárcsak a keménység esetében, minél nagyobb a viszonyszám értéke, annál nagyobb mértékü a javulás.

\section{Eredmények}

A mérési eredményeket és a számított javulási viszonyszámokat az I. esetre vonatkozóan a 2. táblázat, a II. esetre a 3. táblázat foglalja össze.

\begin{tabular}{|c|c|c|c|c|c|c|c|c|c|}
\hline \multirow{2}{*}{ Ssz. } & \multicolumn{2}{|c|}{$\sigma_{t}[\mathrm{MPa}]$} & \multirow{2}{*}{$\begin{array}{l}\Delta \rho_{\sigma \mathrm{t}} \\
{[\%]}\end{array}$} & \multicolumn{2}{|c|}{$\sigma_{\mathrm{a}}[\mathrm{MPa}]$} & \multirow{2}{*}{$\begin{array}{l}\Delta \rho_{\sigma \mathrm{a}} \\
{[\%]}\end{array}$} & \multicolumn{2}{|c|}{ Keménység [HV] } & \multirow{2}{*}{$\begin{array}{c}\Delta \rho_{\mathrm{HV}} \\
{[\%]}\end{array}$} \\
\hline & esztergált & vasalt & & esztergált & vasalt & & esztergált & vasalt & \\
\hline 1 & $-9,5$ & $-187,0$ & 1868,4 & 74,5 & $-217,0$ & 391,3 & 165,7 & 172,3 & 4,02 \\
\hline 2 & $-9,5$ & $-142,3$ & 1397,9 & 74,5 & $-202,7$ & 372,1 & 155,7 & 168,7 & 8,34 \\
\hline 3 & $-9,5$ & $-194,1$ & 1943,2 & 74,5 & $-300,3$ & 503,1 & 168,3 & 170,3 & 1,19 \\
\hline 4 & $-9,5$ & $-183,5$ & 1831,6 & 74,5 & $-307,9$ & 513,3 & 157,0 & 172,0 & 9,55 \\
\hline 5 & $-9,5$ & $-152,8$ & 1508,4 & 74,5 & $-212,9$ & 385,8 & 156,7 & 161,0 & 2,76 \\
\hline 6 & $-18,5$ & $-115,1$ & 522,2 & 67,0 & $-167,1$ & 349,4 & 149,0 & 167,0 & 12,08 \\
\hline 7 & $-18,5$ & $-198,7$ & 974,1 & 67,0 & $-308,9$ & 561,0 & 160,7 & 173,0 & 7,67 \\
\hline 8 & $-18,5$ & $-132,5$ & 616,2 & 67,0 & $-198,9$ & 396,9 & 178,3 & 179,0 & 0,38 \\
\hline
\end{tabular}

2. táblázat. A mért értékek és a számitott viszonyszámok értékei I. 
3. táblázat. A mért értékek és a számitott viszonyszámok értékei II.

\begin{tabular}{|c|c|c|c|c|c|c|c|c|c|}
\hline \multirow{2}{*}{ Ssz. } & \multicolumn{2}{|c|}{$\sigma_{t}[\mathrm{MPa}]$} & \multirow{2}{*}{$\rho_{\sigma t}[\%]$} & \multicolumn{2}{|c|}{$\sigma_{\mathrm{a}}[\mathrm{MPa}]$} & \multirow{2}{*}{$\rho_{\sigma a}[\%]$} & \multicolumn{2}{|c|}{ Keménység [HV] } & \multirow{2}{*}{$\rho_{\mathrm{HV}}[\%]$} \\
\hline & esztergált & vasalt & & esztergált & vasalt & & esztergált & vasalt & \\
\hline 1 & 23,4 & $-97,2$ & 315,38 & $-6,1$ & $-163,3$ & 2577,05 & 160,7 & 169,3 & 1,62 \\
\hline 2 & 23,4 & $-89,6$ & 282,91 & $-6,1$ & $-105,9$ & 1636,07 & 160,7 & 180,3 & 12,19 \\
\hline 3 & 23,4 & $-209,3$ & 794,4 & $-6,1$ & $-220,5$ & 3514,75 & 160,7 & 160,0 & $-0,44$ \\
\hline 4 & 23,4 & $-131,5$ & 461,97 & $-6,1$ & $-207,9$ & 3308,19 & 160,7 & 162,0 & 0,81 \\
\hline 5 & 23,4 & $-148,4$ & 534,19 & $-6,1$ & $-191,6$ & 3040,98 & 160,7 & 181,0 & 12,63 \\
\hline 6 & 49,3 & $-71,8$ & 45,64 & 10,5 & $-82,6$ & 686,67 & 162,7 & 170,0 & 4,49 \\
\hline 7 & 49,3 & $-200,3$ & 306,29 & 10,5 & $-294,9$ & 2708,57 & 162,7 & 158,0 & $-2,89$ \\
\hline 8 & 49,3 & $-150,1$ & 204,46 & 10,5 & $-241,1$ & 2196,19 & 162,7 & 170,0 & 4,49 \\
\hline
\end{tabular}

A teljes faktoriális kísérlettervezés alkalmazásával empirikus képletet (5-10) határoztunk meg, a számítások elvégzéséhez és a szemléltetéshez (3.-6. ábra) pedig a MathCAD programot használtuk fel.

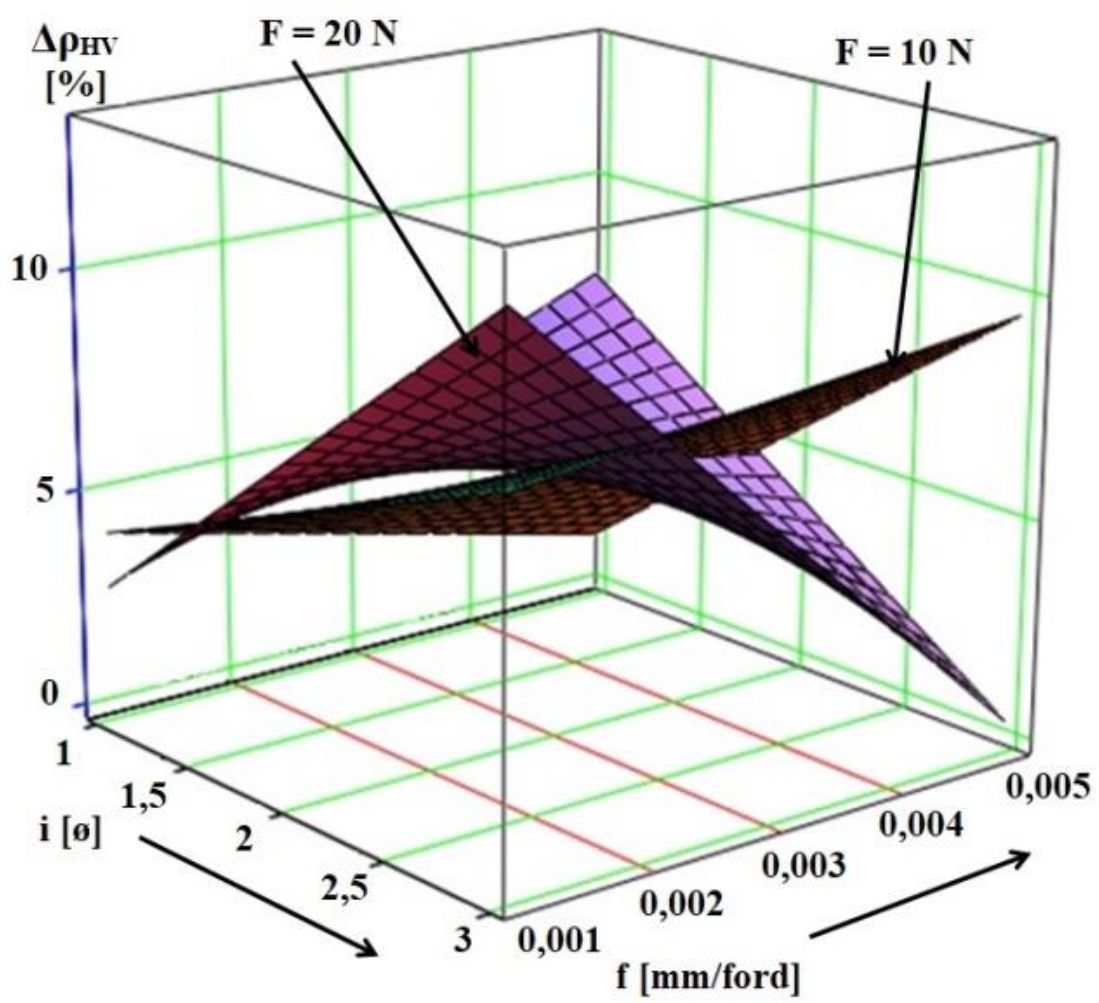

3. ábra Vasalás I.: a felületi mikrokeménység változása

$\Delta \rho_{H V}=11,3488-3,426 \cdot i-5,729 \cdot 10^{3} \cdot f-0,828 \cdot F+3,086 \cdot 10^{3} \cdot i \cdot f++0,508 \cdot i \cdot F+451,625 \cdot$

$$
f \cdot F-258,125 \cdot i \cdot f \cdot F
$$



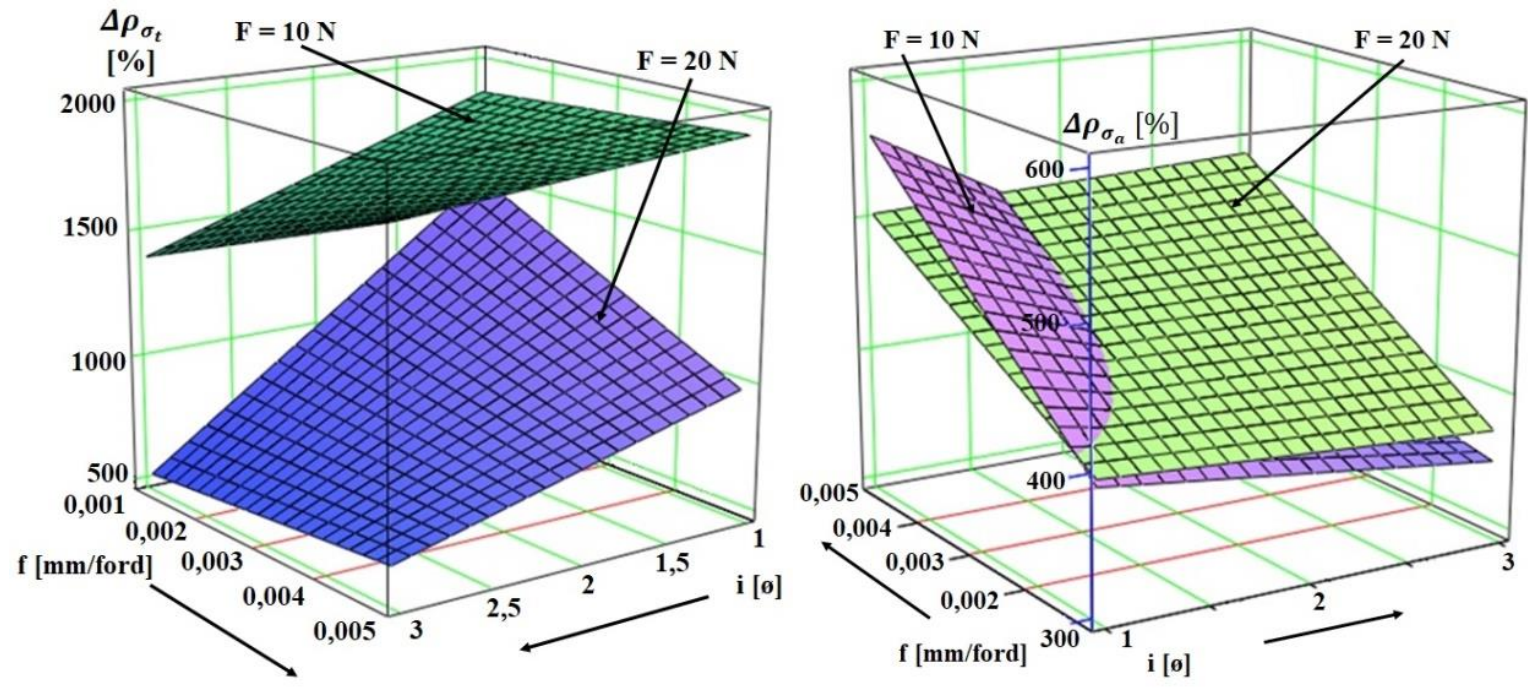

4. ábra Vasalás I.: a feszültségi állapot változása

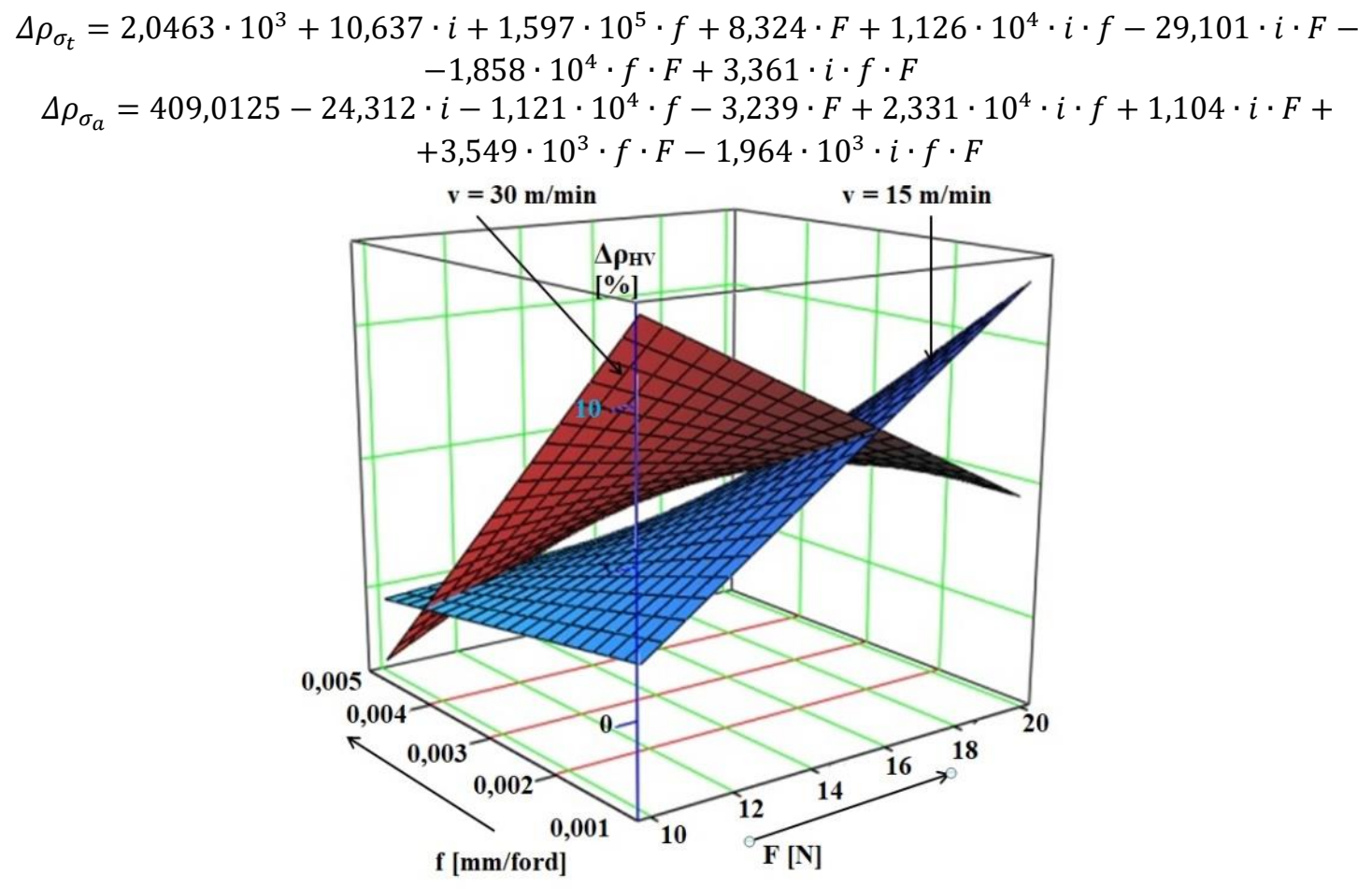

5. ábra Vasalás II.: a felületi mikrokeménység változása

$$
\begin{gathered}
\Delta \rho_{H V}=-50,06+3,782 \cdot F+1,136 \cdot 10^{4} f+2,62 \cdot v-854 \cdot F \cdot f- \\
-0,166 \cdot F \cdot v-638,333 \cdot f \cdot v++41,4 \cdot F \cdot f \cdot v
\end{gathered}
$$



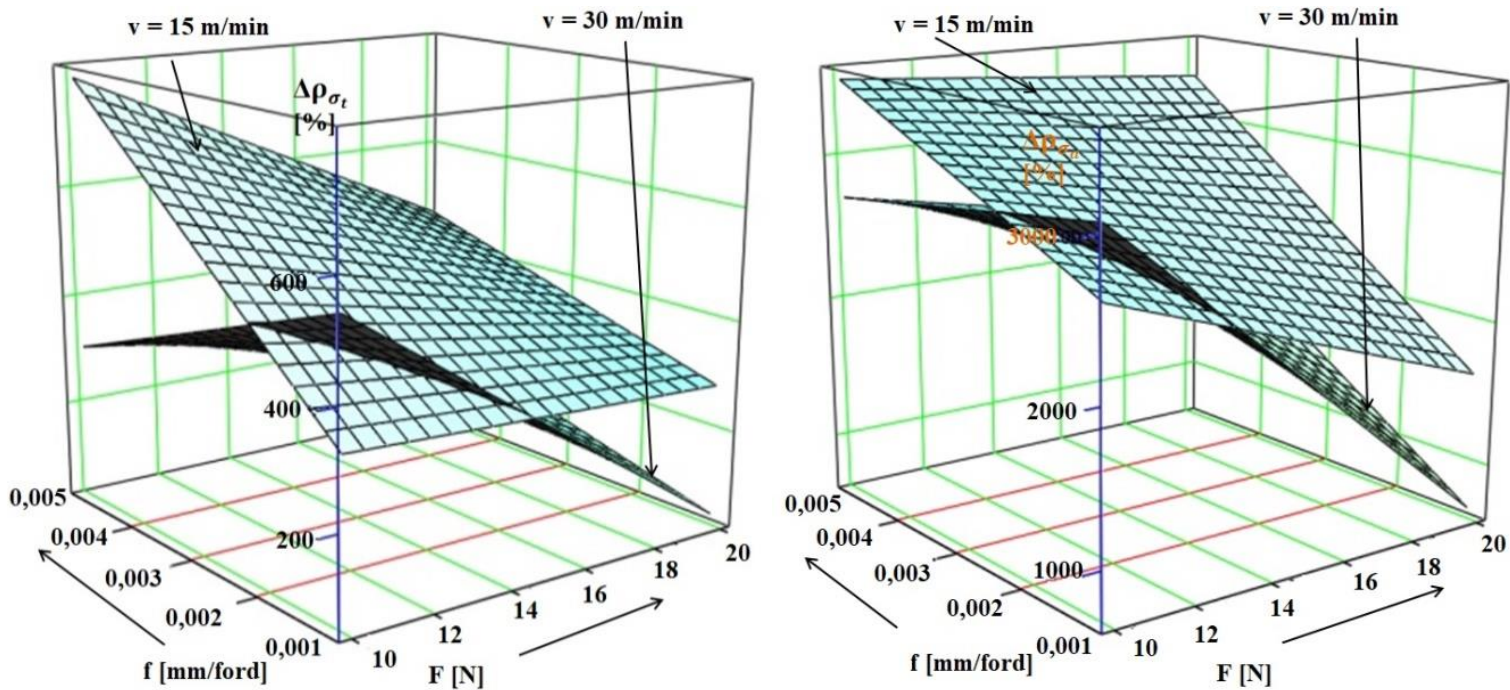

6. ábra Vasalás II.: a feszültségi állapot változása

$$
\begin{gathered}
\Delta \rho_{\sigma_{t}}=-870,185+67,027 \cdot F+5,431 \cdot 10^{5} \cdot F+68,219 \cdot v-2,467 \cdot 10^{4} \cdot F \cdot f-4,185 \cdot F \cdot v- \\
-2,323 \cdot 10^{4} \cdot f \cdot v+1,144 \cdot 10^{3} \cdot F \cdot f \cdot v \\
\Delta \rho_{\sigma_{a}}=995,933+56,523 \cdot F+6,451 \cdot 10^{5} \cdot F+164,752 \cdot v-9,319 \cdot 10^{3} \cdot F \cdot f-11,265 \cdot F \cdot v- \\
-3,962 \cdot 10^{4} \cdot f \cdot v+1,845 \cdot 10^{3} \cdot F \cdot f \cdot v
\end{gathered}
$$

\section{5. Összegzés és következtetések}

Ebben a cikkben a gyémántszerszámos felületvasalással kapcsolatos kísérleti vizsgálataink egy részét taglaltuk gyengén ötvözött alumínium anyagminőség esetére. A vizsgált kísérleti paraméterek a vasalási járatszám, előtolás és erő és járatszám voltak.

A kísérlet célja az volt, hogy elemezzük, ezek a paraméterek hogyan hatnak a felületi mikrokeménységre és feszültségi állapotra, illetve egymással milyen korrelációban állnak, melyhez felhasználtuk a teljes faktoriális kísérlettervezés módszerét. Az eredmények szemléletesebbé tételéhez megalkottunk több dimenzió nélküli viszonyszámot, majd az empirikus képlet definiálását követően a számszerü értékeket 3D-s diagramok formájában is bemutattuk.

Az elvégzett két kísérlet analizált eredményei alapján az alábbi következtetéseket tesszük:

- Egyértelmüen az axiális irányú nyomó maradó feszültség javult nagyobb mértékben, tehát a megmunkálás iránya is hatással van ezen jellemző módosulására;

- A nyomó maradó feszültség értéke növelhető az előtolás növelésével és az erő csökkentésével, a legjobb eredmények az alábbi beállítások mellett adódtak:

Vasalás I.

$\sigma_{\mathrm{t}}$

$$
\begin{aligned}
& \mathrm{i}=1 \\
& \mathrm{f}=0,005 \mathrm{~mm} / \text { ford } \\
& \mathrm{F}=10 \mathrm{~N}
\end{aligned}
$$

$$
\begin{aligned}
& \mathrm{i}=3 \\
& \mathrm{f}=0,005 \\
& \mathrm{~F}=10 \mathrm{~N}
\end{aligned}
$$

Vasalás II.

$$
\sigma_{\mathrm{t}}
$$

$\sigma_{\mathrm{a}}$ 


$$
\begin{array}{ll}
\mathrm{i}=1 & \mathrm{i}=3 \\
\mathrm{f}=0,005 \mathrm{~mm} / \text { ford } & \mathrm{f}=0,005 \\
\mathrm{~F}=10 \mathrm{~N} & \mathrm{~F}=10 \mathrm{~N}
\end{array}
$$

- A keménység szempontjából legnagyobb mértékü javulást pedig a következő paraméterek beállítása esetén tapasztaltuk:

$$
\begin{array}{cc}
\text { Vasalás I. } & \mathrm{i}=3 \\
& \mathrm{f}=0,001 \mathrm{~mm} / \text { ford } \\
& \mathrm{F}=20 \mathrm{~N} \\
\text { Vasalás II. } & \mathrm{F}=10 \mathrm{~N} \\
& \mathrm{f}=0,001 \mathrm{~mm} / \text { ford } \\
& \mathrm{v}=30 \mathrm{~m} / \mathrm{min}
\end{array}
$$

Ennek magyarázata, hogy ezzel a beállítással a hideg képlékeny alakítás, tehát a felkeményedés is hatékonyabban tud megvalósulni, mivel a szerszám mủködő és a munkadarab megmunkálandó felülete nagyobb erővel és hosszabb időtartamban érintkezik, de meg kell jegyezni, hogy a járatszám növelésével is növelhető ez az időtartam, így a felületi mikro-keménység is.

\section{Köszönetnyilvánítás}

„A cikkben ismertetett kutató munka az EFOP-3.6.1-16-2016-00011 jelü „Fiatalodó és Megújuló Egyetem - Innovatív Tudásváros - a Miskolci Egyetem intelligens szakosodást szolgáló intézményi fejlesztése" projekt részeként - a Széchenyi 2020 keretében - az Európai Unió támogatásával, az Európai Szociális Alap társfinanszírozásával valósul meg".

\section{Irodalom}

[1] Bednarski, P., Bialo, D., Brostow, W., Czechowski, K., Polowski, W., Rusek, P., Tobola, D.: Improvement of tribological properties of metal matrix composites by means of slide burnis-

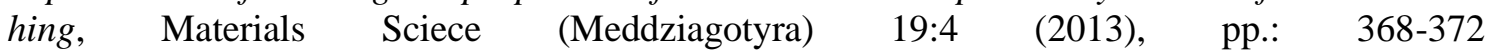
https://doi.org/10.5755/j01.ms.19.4.2404

[2] Varga, G., Sovilj, B., Pasztor, I.: Experimental Analysis of Sliding Burnishing, Academic Journal of Manufacturing Engineering 11:3 (2013), pp.: 6-11

[3] Stalin John, M., Suresh, P., Raguramand, D., Vinayagam, B. K.: Surface characteristics of low plasticity burnishing for different materials using lathe, Arab J SciEng. 39 (2014), pp.: 32093216 https://doi.org/10.1007/s13369-013-0923-4

[4] Akkurt, A.: Comparison of roller burnishing and other methods of finishing treatment of the surface of openings in parts from tool steel D3 for cold forming, Journal of Materials Engineering and Performance 20:6 (2011), pp 960-968

[5] Luca, L., Neagu-Ventzel, S., Marinescu, I., Effects of working parameters on surface finish in ball-burnishing of hardened steels, Precision Engineering 29 (2005), pp.: 253-256 https://doi.org/10.1016/j.precisioneng.2004.02.002

[6] El-Taweel, T.A., El-Axir, M.H.: Analysis and optimization of the ball burnishing process through the Taguchi technique, The International Journal of Advanced Manufacturing Technology 41 (2009), pp. 301-310 https://doi.org/10.1007/s00170-008-1485-6 
[7] Varga, G.: Effects of Technological Parameters on the Surface Texture of Burnished Surfaces, Key Engineering Materials 581: Precision Machining VII (2014), pp.: 403-408, 2014 https://doi.org/10.4028/www.scientific.net/KEM.581.403

[8] M.Hassan, A., Al-Bsharat, A.S.: Influence of Burnishing Process on Surface Roughness, Hardness, and Microstructure of Some Non-Ferrous Metals, Wear 199 (1996), pp.: 1-8 https://doi.org/10.1016/0043-1648(95)06847-3

[9] Toboła, D., Rusek, P., Czechowski, K., Miller, T., Duda, K.: New Indicators of Burnished Surface Evaluation - Reasons of Application, Metrol, Meas. Syst. XXII: 2 (2015), pp.: 263-274 https://doi.org/10.1515/mms-2015-0018

[10] Sequera, A., Fu, C. H., Guo, Y. G., Wei, X.T.: Surface Integrity of Inconel 718 by Ball Burnishing, Journal of Materials Engineering and Performance (2014), pp.: 3347-3353 https://doi.org/10.1007/s11665-014-1093-6

[11] Fridrik, L.: Válogatott fejezetek a gépgyártástechnológiai kísérletek tervezése témaköréböl, (1989) Budapest, p.:109

[12] Mertinger, V., Sólyom, J., Cseh, D.: Maradó feszültség vizsgálata röntgendiffrakcióval, Segédlet TÁMOP-4.2.1.B/-10/2/KONV-2010-0001 (2012), pp.: 1-39

[13] Mertinger, V., Benke, M.: Fémfelületek röntgendiffrakciós vizsgálatainak speciális lehetöségei, Archeometriai Mühely 12:1 (2015), pp.: 15-24

[14] Fitzpatrick, M.E., Fry, A.T., Holdway, P., Kandil, F.A., Shackleton, J., Suominen, L.: Determination of residual stress by X-ray diffraction, Measurement Good Practice Guide (2005), p.: 68 